\title{
ANALISIS GENDER DALAM PEMBAJAKAN PRODUK DIGITAL
}

\section{GENDER ANALYSIS IN DIGITAL PRODUCT PIRACY}

\author{
Aditya Pandu Wicaksono ${ }^{1}$, Dekar Urumsah ${ }^{1}$ \\ ${ }^{12}$ Universitas Islam Indonesia \\ 1'aditya.pandu@uii.ac.id, ${ }^{2}$ dekar.urumsah@uii.ac.id
}

\begin{abstract}
Abstrak
Di era teknologi yang canggih pembajakan produk digital sangat mungkin untuk dilakukan oleh siapapun. Kasus ini sangat sulit untuk dicegah namun harus dilakukan. Penelitian ini bertujuan untuk menginvestigasi factor-faktor yang mendorong perilaku pembajakan digital. Penelitian ini menitikberatkan pada analisis gender berdasarkan pada model penelitian yang dibuat. Penelitian ini menggunakan model dari TAM yang tidak digunakan oleh penelitian sebelumnya. Sampel penelitian adalah mahasiswa S1 di Yogyakarta dengan menerapkan teknik convenience, purposive, dan snowball. Dengan menggunakan kuesioner daring, penelitian ini memperoleh data dari 94 mahasiswa dan 115 mahasiswi. Hasil menunjukkan tidak ada perbedaan signifikan antara mahasiswa dan mahasiswi dalam perilaku pembajakan. Mahasiswa sulit untuk menerima harga dari produk digital yang asli sedangkan mahasiswi bersedia untuk membayar. Penelitian ini mengingatkan perusahaan untuk lebih memperhatikan keamanan penjualan produk digitalnya. Selain itu, pemerintah dan perusahaan perlu untuk berkolaborasi memerangi pembajakan juga memperkuat perlindungan hak cipta.
\end{abstract}

Kata kunci: Pembajakan, Model Penerimaan Teknologi, Gender

\begin{abstract}
In this technology-based era, digital piracy is very likely to be conducted by people who have experience with technology. It is difficult to combat piracy, however, the action must be taken. This research aims to investigate factors which drive digital piracy behavior. In addition, this research emphasizes on the gender analysis based on the developed research model. This research used the technology acceptance model (TAM) which is not involved in the previous researches. The research samples are undergraduate students in Yogyakarta treated by using convenience, purposive, and snowball technique. By implementing online questionnaires, the data are gained from 94 male students and 115 female students. The result shows that there is no significant difference between male and female students in piracy behavior. Male students do not accept the genuine digital's price however female students do not have a problem with that. This research reminds company to pay attention to the security aspect. Additionally, the government and company need to collaborate combating digital piracy and enhancing copyright protection.
\end{abstract}

Keyword: Piracy, Technology Acceptance Model, Gender

\section{PENDAHULUAN}

Sejak dua dekade terakhir telah terdapat peningkatan permintaan terhadap jasa internet dan penggunaan teknologi informasi (TI) di seluruh dunia termasuk Indonesia (Abbasi, Chandio, Soomro, \& Shah, 2011). Survei yang dilakukan di Indonesia menemukan bahwa 132,7 juta penduduk Indonesia telah terhubung dengan internet dari 256,2 juta penduduk Indonesia secara keseluruhan (Widiartanto, 2016). Angka tersebut menempatkan Indonesia di ranking enam dunia negara dengan pengguna internet terbesar. Penyebab dari banyaknya 
pengguna internet dikarenakan peningkatan infrastruktur dan mudahnya memperoleh smartphone dan peralatan genggam (Widiartanto, 2016). Atas dasar ini, berbagai industri produk intelektual (musik, buku, film, software, dll) menangkap peluang bisnis untuk memperoleh profit dengan internet. Akhirnya, industri tersebut menambah proses penjualan tidak hanya konvensional (menggunakan kaset, CD/DVD, dll) tetapi dijual ke dalam format digital yang dijual dengan mengunduh di internet.

Namun, terdapat tantangan yang harus dihadapi oleh industri produk intelektual dengan format digital yaitu perilaku pembajakan digital (digital piracy). Terminologi pembajakan digital merujuk pada penggandaan, pembagian, pembelian dan atau mengunduh software, produk musik, video, buku, dan gambar yang berlisensi (Tjiptono, Arli, \& Viviea, 2016). Jackman \& Torde (2014) berpendapat bahwa penjualan format digital melalui internet telah membuka cara baru dalam perilaku pencurian. Sudler (2013) menjelaskan pembajakan terjadi karena perkembangan infrastruktur dan kecepatan internet yang pesat. Bagaimanapun perilaku mengunduh yang muncul akibat dari internet membuat penggunanya leluasa mencari produk digital di internet (Jacobs, Heuvelman, Tan, \& Peters, 2012). Pengguna internet dapat dengan mudah menemukan produk bajakan di internet yang dapat diunduh melalui komputer atau gadget. Beberapa situs di Indonesia dan dunia menanamkan konten produk bajakan yang mana susah untuk dilacak tetapi sangat mudah untuk dihapus oleh pemilik situs sebelum penegakan hukum diterapkan. Untuk lebih menghindari tuntutan hukum, situs-situs tersebut memberikan penyangkalan yang mengatakan bahwa "kami hanya menyediakan konten yang tertanam dari server asing dan kami hanya mengimpornya dari situs lain. Kami juga tidak menyediakan atau mengunggah konten berhak cipta di server kami" (Jakarta Globe, 2017).

Penelitian telah mengungkapkan bahwa pembajakan digital dilakukan karena didorong oleh berbagai faktor yang mendasarinya. Arli \& Tjiptono (2016) menemukan bahwa orang Indonesia tidak takut dengan konsekuensi legal atas perilaku pembajakan digital yang dilakukan serta adanya persepsi benefit yang digunakan sebagai justifikasi pembajakan digital. Yoon (2011) dengan menggunakan theory of planned behavior (TPB) menemukan bahwa konstruk dalam TPB (attitude, subjective norm, dan perceived behavioral control) mendorong untuk memunculkan niat melakukan pembajakan. Carmen, Carmen, \& Javier (2014) menjelaskan bahwa penerimaan terhadap harga produk berlisensi menjadi pemicu utama perilaku pembajakan.

Untuk investigasi lebih dalam, penelitian menggunakan gender untuk menganalisa apakah laki-laki atau perempuan yang lebih dominan dalam pembajakan digital. Terdapat perbedaan hasil diantara penelitian gender terhadap perilaku pembajakan. Jackman \& Torde (2014) menemukan bahwa tidak ada perbedaan yang signifikan antara laki-laki dan perempuan terhadap niat pembajakan. Hal yang sama juga ditemukan oleh Al-rafee \& Cronan (2006). Tetapi hasil dari Cockrill \& Goode (2012) dan Chiang \& Assane (2008) menunjukan adanya perbedaan antara laki-laki dan perempuan. Perempuan memiliki lebih besar persepsi resiko dan keinginan untuk membeli produk berlisensi dibandingkan dengan laki-laki (Chiang \& Assane, 2008). Sekarang ini, tidak ada kesepakatan siapakah yang lebih etis antara laki-laki dan perempuan (Bossuyt \& Van Kenhove, 2016). Oleh karena itu, penjelasan mengenai gender masih memerlukan banyak penelitian (Tjiptono et al., 2016). Di area pembajakan digital, studi menyatakan bahwa orang Asia cenderung lebih menerima barang bajakan dengan mengabaikan etika (Swinyard et al., 1990). Namun pengujian mengenai gender terhadap perilaku pembajakan belum banyak dilakukan diwilayah Asia, khususnya di negara berkembang seperti Indonesia. Penelitian terdahulu yang menguji gender terhadap pembajakan digital di Indonesia (Tjiptono et al., 2016) belum membentuk suatu model penelitian yang kemudian diuji secara terpisah baik pengujian untuk laki-laki maupun perempuan. 
Penelitian ini bertujuan untuk menginvestigasi faktor gender terhadap perilaku pembajakan digital melalui pengunduhan ilegal di Indonesia yang didasari dengan variabel yang terdapat dalam technology acceptance model (TAM) dan beberapa faktor potensial yang mendukung investigasi perilaku pembajakan digital. Selain itu, penelitian dengan menggunakan TAM untuk menguji perilaku pembajakan digital dengan spesifik pada gender belum banyak dilakukan. Penelitian pada perilaku pembajakan saat ini masih didominasi oleh model dasar TPB. Oleh karena itu, penelitian ini mempertanyakan sejauh mana faktor penerimaan teknologi (TAM) berperan dalam investigasi perilaku pembajakan. Penelitian ini juga menguji variabel potensial lain seperti subjective norm, penilaian moral, dan penerimaan harga.

\section{Technology Acceptance Model (TAM)}

TAM dibangun oleh Davis (1989) untuk memahami proses psikologikal dari adopsi dan penerimaan terhadap informasi teknologi (Zhang, Nyheum, \& Mattila, 2014). TAM menggunakan TPB (Ajzen, 1991) sebagai dasar untuk menginvestigasi perilaku dalam adopsi dan penerimaan terhadap teknologi. TAM adalah model yang telah diterima secara luas dalam konteks penerimaan sistem dan teknologi informasi. TAM awal mulanya terdiri dari dua variabel dasar yaitu persepsi manfaat (perceived usefulness) dan persepsi kemudahan penggunaan (perceived ease of use) yang mempengaruhi penerimaan terhadap sistem maupun teknologi informasi (Davis, 1989). Dalam perkembangannya, persepsi manfaat dan persepsi kemudahaan menjadi mediasi antara eksternal variabel terhadap niat berperilaku, yang kemudian dikenal dengan TAM 3 (Venkatesh \& Bala, 2008).

Di area pembajakan digital, belum banyak penelitian yang mengadopsi TAM untuk menginvestigasi perilaku pembajakan. Penelitian ini menganggap bahwa TAM mampu untuk menjadi model dasar untuk mengidentifikasi faktor yang mempengaruhi perilaku pembajakan. Carmen et al. (2014) telah membuktikan bahwa TAM (persepsi manfaat dan persepsi kemudahan) memiliki peran dalam pembajakan atau mengunduh secara ilegal produk buku elektronik (e-book). Peran dari persepsi manfaat dan kemudahan sedikit berbeda dalam menjelaskan antara penerimaan teknologi dan perilaku pembajakan. Dalam area penerimaan teknologi, persepsi manfaat dan kemudahan merupakan suatu persepsi individu bahwa dengan menggunakan teknologi akan memperoleh benefit seperti meningkatakan kinerja serta bebas dari usaha. Namun di area pembajakan digital, persepsi kemudahan didefinisikan sebagai tingkat kemudahan individu memperoleh produk bajakan yang lebih murah atau bebas dari usaha seperti bebas dari biaya (gratis) dengan menggunakan teknologi informasi (TI). Persepsi manfaat diartikan sebagai tingkat dari individu bahwa manfaat dari produk digital bajakan hampir sama bahkan sama atau dapat menggantikan manfaat dari produk yang asli. Dari penjelasan di atas memberikan informasi bahwa TAM dapat digunakan tidak hanya dalam penerimaan teknologi tetapi juga dalam isusisu yang memungkinkan TAM memiliki peran untuk menjelaskan isu tersebut.

\section{Gender pada Teknologi}

Venkatesh \& Morris (2000) memberikan pandangan penerimaan teknologi berdasarkan gender dengan mengadopsi model dasar TAM (Davis, 1989). Hasil dari penelitian Venkatesh \& Morris (2000) menunjukan adanya perbedaan hasil antara laki-laki dan perempuan terhadap persepsi manfaat dan kemudahan. Temuan menjelasakan bahwa laki-laki lebih melihat sisi manfaat sebelum memutuskan untuk menggunakan teknologi baru. Hasil yang berbeda pada persepsi kemudahan, persepsi kemudahan bukanlah faktor yang menarik untuk laki-laki, namun menjadi faktor yang menonjol untuk perempuan dalam memutuskan penggunaan teknologi baru. Untuk membuat pengujian lebih komprehensif, Venkatesh \& Morris (2000) mengambil satu variabel dalam model TPB yaitu subjective norm yang berarti pengaruh dari lain atau lingkungan untuk melakukan perilaku dalam hal 
ini adalah teknologi. Subjective norm tidak berpengaruh untuk laki-laki namun menjadi pengaruh yang dipertimbangkan bagi perempuan.

Penelitian lain menjelaskan gender terhadap teknologi dari berbagai perspektif yang menemukan bukti perbedaan laki-laki dan perempuan ketika dihadapkan dengan teknologi. Vekiri \& Chronaki (2008) menggunakan siswa sebagai objek penelitian untuk diteliti penerimaan teknologi berdasarkan gender. Meskipun seluruh siswa memiliki komputer dan internet, terdapat perbedaan yang signifikan antara siswa laki-laki dan perempuan. Siswa laki-laki lebih bereaksi positif terhadap teknologi dan memiliki keahlian lebih tinggi terhadap komputer dibandingkan siswi perempuan. Siswa laki-laki lebih banyak dukungan dari keluarga dan lingkungan sekitarnya Vekiri \& Chronaki (2008). Di tingkat pelajar di perguruan tinggi (setelah ini disebut mahasiswa dan mahasiswi), He \& Freeman (2010) menemukan bahwa mahasiswi merasa kurang percaya diri menggunakan teknologi karena kurang mempelajari dan praktik serta merasa lebih cemas dengan teknologi daripada mahasiswa. Penelitian dari Anderson, Lankshear, Timms, \& Courtney (2008) mengindikasikan bahwa umumnya perempuan lebih rendah penerimaannya terhadap teknologi akibat mudah bosan karena teknologi tidak relevan dengan kebutuhannya.

Di lain pihak, beberapa penelitian menemukan bahwa laki-laki dan perempuan tidak berbeda perilakunya terhadap teknologi. Jennings \& Onwuegbuzie (2001) menemukan gender bukanlah faktor yang berhubungan dengan perilaku teknologi. Hasil tersebut menunjukan bahwa gender gap (Moghaddam, 2010) perilaku terhadap teknologi sudah berkurang. Popovich, Gullekson, \& Morris, 2008) menemukan hal yang sama bahwa lakilaki dan perempuan tidak lagi berbeda dengan signifikan ketika berhadapan dengan teknologi.

\section{Gender, Teknologi, dan Faktor yang Berkaitan Terhadap Pembajakan Digital}

Gender adalah salah satu variabel yang paling sulit untuk diinvestigasi di area etika bisnis sejak diidentifikasi sebagai faktor yang penting dalam mempengaruhi etika termasuk pembajakan digital (Al-rafee \& Cronan, 2006; Tjiptono et al., 2016). Pembajakan digital didefinisikan sebagai penggandaan, pembelian, pembagian dan atau mengunduh secara ilegal produk digital yang memiliki hak cipta seperti software, produk audio, video, buku, dan gambar (Tjiptono et al., 2016). Memahami faktor yang mendorong perilaku pembajakan telah dilakukan oleh Carmen et al. (2014) yang menemukan bahwa perilaku pembajakan dipengaruhi oleh faktor teknologi dari individu. Temuan menjelaskan persepsi manfaat dan persepsi kemudahan mendorong terjadinya pembajakan ketika didefinisikan sebagai kemudahan penggunaan IT untuk memperoleh produk bajakan dan memperoleh manfaat dari produk bajakan tersebut. Namun penjelasan terkait gender belum dilakukan di penelitian tersebut.

Aspek lain yang menjadi perhatian dalam investigasi faktor pembajakan digital adalah subjective norm. Subjective norm merupakan variabel yang membangun TPB (Ajzen, 1991) yang kemudian diadopsi oleh Venkatesh \& Bala (2008) sebagai eksternal variabel dalam TAM 3. Di area penelitian pembajakan digital, subjective norm telah diadopsi untuk lebih komprehensif menginvestigasi pembajakan digital seperti yang dilakukan (Phau, Lim, Liang, \& Lwin, 2014; Yoon, 2011). Phau et al. (2014) menemukan terdapat hubungan positif antara subjective norm dengan pembajakan digital. Individu yang mudah dipengaruhi akan lebih cenderung mudah untuk melakukan pembajakan digital. Namun demikian, belum dijelaskan secara spesifik apakah individu yang mudah dipengaruhi adalah laki-laki atau perempuan. Kembali ke penelitian Venkatesh \& Morris (2000) tentang penerimaan teknologi berdasarkan gender, laki-laki tidak terpengaruh sedangkan perempuan akan mempertimbangkan pengaruh tersebut. Dikaitkan dengan pembajakan digital, asumsi yang muncul berdasarkan hasil Venkatesh \& Morris (2000) adalah laki-laki tidak terpengaruh oleh 
pengaruh untuk membajak sedangkan perempuan akan mempertimbangkan sesuatu sebelum melakukan pembajakan.

Alasan untuk melakukan suatu perilaku pembajakan digital bahwa orang percaya mereka akan menghemat biaya dengan membajak produk digital. Faktor lain yang berhubungan dan signifikan dengan pembajakan digital adalah harga produk digital yang sangat mahal (overpriced) (Al-rafee \& Cronan 2006). Saat ini, sebagian besar orang menyalahkan harga yang overpriced untuk meningkatkan perilaku pembajakan (Carmen et al., 2014). Seperti yang diitemukan Zimerman (2011) bahwa harga yang tinggi berkontribusi meningkatkan persepsi peretasan dan perilaku pembajakan. Konsumen telah menyadari bahwa biaya untuk membuat suatu produk digital tidak sama mahalnya dengan produk konvensional. Easley (2005) menduga bahwa mereka yang membajak akan membeli harga produk digital yang asli dengan harga yang wajar.

Dalam penelitiannya, Easley (2005) mempertanyakan apakah pembajakan tergolong perilaku tidak etis atau hanya dianggap ilegal. Balestrino (2008) menyebutkan bahwa pembajakan adalah merusak etika yang tergolong pencurian namun tidak diklasifikasikan dengan tegas sebagai perilaku kriminal. Secara khusus untuk investigasi di area gender menggunakan gender socialization theory bahwa laki-laki dan perempuan memiliki sifat dan nilai yang berbeda yang diterjemahkan ke dalam orientasi moral yang berbeda (Bossuyt \& Van Kenhove, 2016). Menurut teori tersebut, perempuan lebih sensitif, berorientasi pada orang lain, dan lebih mematuhi peraturan, sedangkan laki-laki lebih rasional, individualistik, dan cenderung melanggar peraturan (Roxas \& Stoneback, 2004). Teori tersebut tidak mendukung penelitian dari Tjiptono et al. (2016), yang mengindikasikan pembajakan dipersepsikan suatu perilaku yang diterima baik oleh laki-laki maupun perempuan. Di sisi lain, pada penerimaan harga, Chiang \& Assane (2008) menemukan bahwa perempuan lebih menghindari resiko dan cenderung memiliki keinginan untuk membayar produk digital jika dibandingkan dengan laki-laki.

Berdasarkan faktor-faktor yang mempengaruhi perilaku pembajakan digital, penelitian ini membangun sebuah model penelitian untuk menuntun investigasi yang dilakukan. Penelitian ini hanya akan berfokus pada perspektif gender yang mana akan dilakukan pengujian terpisah untuk setiap jenis kelamin yaitu laki-laki dan perempuan. Model penelitian seperti yang tergambar dalam Gambar 1 di bawah ini. Oleh karena itu, hipotesis yang ditekankan dalam penelitian ini adalah sebagai berikut:

$\mathbf{H}_{1}$ : Apakah mahasiswa dan mahasiswi terdapat perbedaan dalam perilaku pembajakan digital

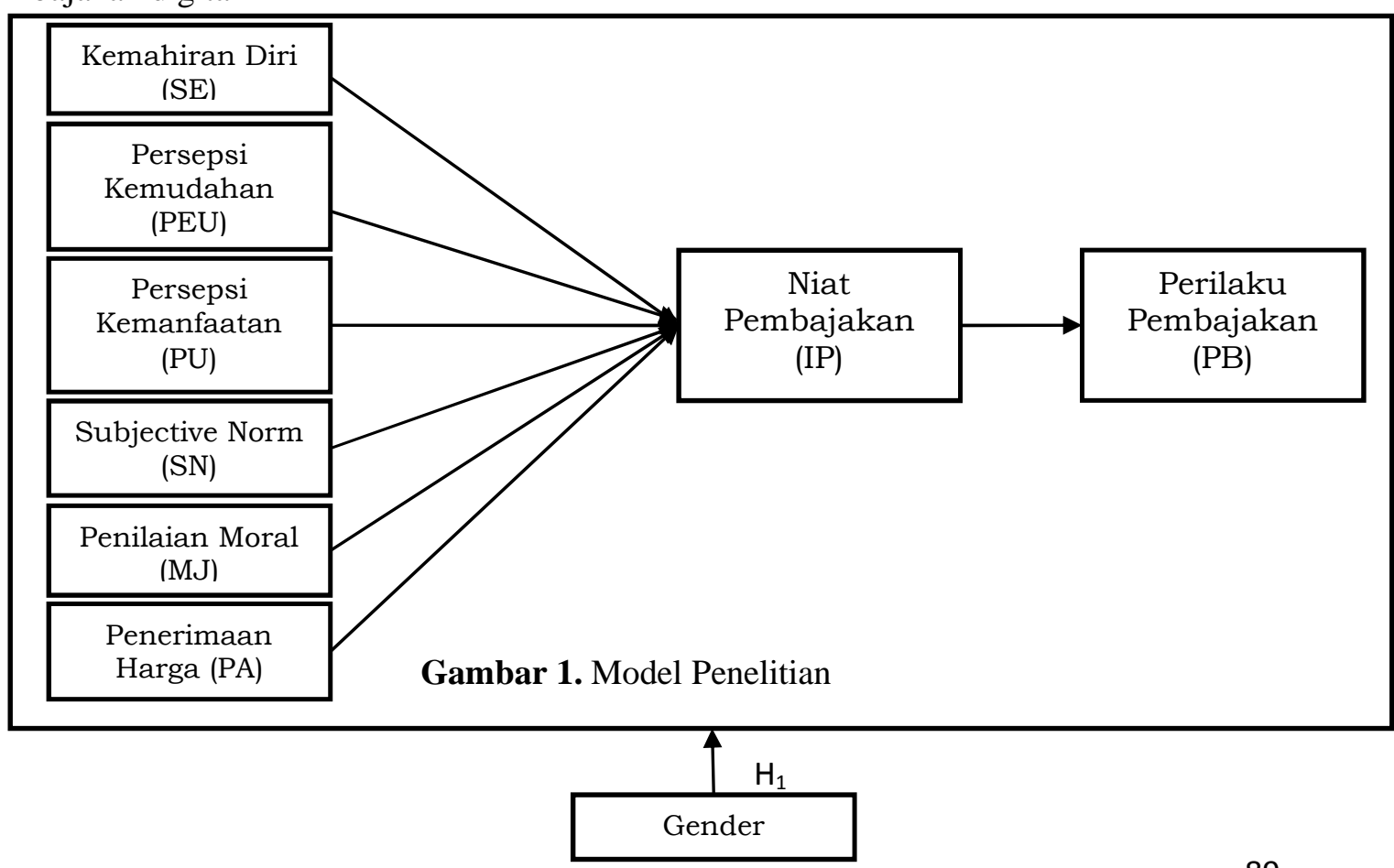




\section{METODE}

Penelitian ini menggunakan sampel mahasiswa sebagai responden untuk penelitian ini. Terdapat dua alasan mengapa mahasiswa dipilih sebagai responden. Pertama, berdasarkan informasi dari CNN Indonesia (2016), lebih dari 80\% pengguna internet di Indonesia adalah generasi muda dengan rentang usia 20-24 tahun dan 25-29 tahun. Pada usia 20-24 tahun pengguna internet diketahui sebanyak 22,3 juta jiwa sedangkan usia 25-29 tahun terdapat 24 juta pengguna internet. Data tersebut menunjukan bahwa pengguna internet di Indonesia didominasi oleh generasi muda pada rentang usia mahasiswa. Kedua, mahasiswa memiliki proporsi terbesar dalam melakukan pembajakan digital (Arli \& Tjiptono, 2016; Phau \& Liang, 2012; Tjiptono et al., 2016; Yoon, 2011). Pembajakan sangat lazim terjadi di dunia akademis daripada di dunia bisnis dimana universitas adalah tempat perkembangbiakan yang ideal untuk pembajakan (Tjiptono et al., 2016). Mahasiswa sebagai pelaku pembajakan dengan porsi terbesar sebagai dampak dari koneksi internet kecepatan tinggi dan mempunyai cukup waktu untuk melakukan pembajakan (Arli \& Tjiptono, 2016).

Penelitian ini dilakukan di Daerah Istimewa Yogyakarta (DIY) yang dikenal dengan kota pelajar yang memiliki banyak sekolah tinggi/universitas baik negeri maupun swasta (Tjiptono et al., 2016). Alasan memilih DIY sebagai area penelitian karena DIY merupakan tujuan pendidikan dari calon mahasiswa dan mahasiswi dari berbagai daerah di Indonesia. Sekolah tinggi/universitas di DIY umumnya memiliki mahasiswa dan mahasiswi yang berasal dari luar DIY bahkan pulau Jawa, sehingga mengambil DIY sebagai area penelitian dianggap mampu untuk merefleksikan mahasiswa di Indonesia.

Penelitian ini menggunakan kuesioner secara elektronik yang dibantu dengan google form untuk disebarkan kepada responden. Pengambilan sampel menggunakan pendekatan convenience, purposive, dan snowball sampling. Convenience sampling digunakan untuk meyebar kuesioner kepada mahasiswa dan mahasiswi secara acak tanpa melihat karakteristik terentu. Tetapi dibatasi dengan purposive sampling yang membatasi mahasiswa sebagai responden untuk memenuhi karakteristik tertentu, yaitu mahasiswa dan mahasiswi yang pernah melakukan illegal downloading atau pembajakan. Kemudian snowball sampling digunakan untuk memperoleh responden dalam jumlah yang lebih besar berdasarkan rekomendasi dari responden untuk memperoleh responden yang pernah melakukan illegal downloading atau pembajakan. Kuesioner elektronik telah diisi oleh 216 mahasiswa strata-1 dari berbagai sekolah tinggi/universitas di Yogyakarta. Dari jumlah tersebut terdapat 7 kuesioner diisi tidak lengkap sehingga tidak dilibatkan dalam penelitian. Demografi dari responden adalah sebagai berikut: 115 responden adalah mahasiswi, sedangkan 94 responden adalah mahasiswa.

Penelitian ini menggunakan item pertanyaan yang telah terbukti valid dalam penelitian sebelumnya. Setiap item pertanyaan berisi skala likert dengan jarak 1 (sangat tidak setuju) hingga 6 (sangat setuju). Kemahiran diri diukur menggunakan 5 item pertanyaan yang dikembangkan oleh Venkatesh \& Bala (2008); He \& Freeman (2010). Persepsi kemudahan dan manfaat diukur masing-masing dengan 6 item untuk persepsi kemudahan dan 5 item untuk persepsi manfaat yang diadopsi dari (Carmen et al., 2014; Venkatesh \& Bala, 2008). Subjective norm diukur dengan 4 item pentanyaan yang telah dilakukan oleh Yoon (2011). Penilaian moral diukur dengan 4 item pertanyaan dari penelitian Phau et al. (2014). Penerimaan harga diukur dengan 5 item yang dikembangkan dari penelitian Carmen et al. (2014). Niat melakukan pembajakan diukur dengan 3 item yang telah digunakan dalam penelitian Yoon (2011) dan Phau et al. (2014). Perilaku pembajakan produk digital diukur dengan 4 item pertanyaan yang diadopsi dari Arli, Tjiptono, \& Porto (2015). 


\section{HASIL DAN PEMBAHASAN}

\section{Hasil Statistik pada Gender}

Penelitian ini menggunakan smartPLS untuk menginvestigasi hubungan seperti yang ditampilkan dalam Gambar 1. Terdapat dua model yang tersedia dalam investigasi menggunakan smartPLS yaitu model pengukuran dan model struktural. Model pengukuran berisi dua pengujian dasar untuk menilai item dan variabel. Pertama, pengujian validitas untuk item pertanyaan yang digunakan dalam penelitian ini. Convergent validity dibangun untuk menguji signifikansi dari individual item loadings menggunakan nilai t ( $t$-value). Untuk memenuhi convergent validity, nilai dari outer loading masing-masing item lebih dari 0.5 untuk dapat diterima. Selain itu, nilai average variance extracted (AVE) setiap variabel harus lebih besar dari 0,5 (Gefen, Straub, \& Boudreau, 2000). Kedua, pengujian reliabilitas dilakukan untuk menilai apakah variabel yang digunakan dalam penelitian ini dapat diandalkan. Untuk membentuk reliabilitas, nilai dari composite reliability $(\mathrm{CR})$ setidaknya memiliki nilai 0,6 tetapi akan lebih baik jika bernilai 0,7 (Hair, Black, Babin, Anderson, \& Tatham, 2010). Pengujian validitas dan reliabilitas dilihat sesuai dengan subgroup yaitu gender sehingga validitas dan reliabilitas setiap item dan variabel dihitung terpisah berdasarkan data yang dikumpulkan dari laki-laki dan perempuan. Hasil perhitungan validitas dan reliabilitas tersaji di dalam tabel 1 .

Tabel 1. Loading, $t$-value, AVE, dan CR dari Subgrup Gender

\begin{tabular}{ccccc}
\hline \multirow{2}{*}{ ITEM } & \multicolumn{2}{c}{ MAHASISWA } & \multicolumn{2}{c}{ MAHASISWI } \\
\cline { 2 - 5 } & loading & $\boldsymbol{t}$-value & loading & t-value \\
\hline SE1 & 0,7843 & 73,7266 & 0,8590 & 78,2912 \\
SE2 & 0,8925 & 141,6696 & 0,8914 & 130,8164 \\
SE3 & 0,8935 & 138,864 & 0,9211 & 261,2029 \\
SE4 & 0,8784 & 129,5970 & 0,8124 & 70,3540 \\
SE5 & 0,7124 & 53,4629 & 0,8163 & 96,1703 \\
PEU1 & 0,6486 & 38,0875 & 0,6859 & 44,9201 \\
PEU2 & 0,8570 & 153,6516 & 0,8451 & 162,6672 \\
PEU3 & 0,8399 & 96,5123 & 0,8705 & 140,4161 \\
PEU4 & 0,7825 & 60,1625 & 0,7693 & 50,6754 \\
PEU5 & 0,5153 & 15,9493 & 0,6710 & 34,5797 \\
PEU6 & 0,7483 & 52,1711 & 0,7475 & 52,3711 \\
PU1 & 0,9052 & 191,5227 & 0,8825 & 158,5878 \\
PU2 & 0,9264 & 286,1612 & 0,9201 & 237,0676 \\
PU3 & 0,9078 & 206,8549 & 0,8829 & 135,1087 \\
PU4 & 0,8505 & 114,9801 & 0,8491 & 83,8467 \\
PU5 & 0,8107 & 74,2859 & 0,8074 & 79,5431 \\
SN1 & 0,7072 & 35,6423 & 0,5903 & 19,2884 \\
SN2 & 0,7879 & 64,2745 & 0,6740 & 35,7933 \\
SN3 & 0,7931 & 46,9582 & 0,8210 & 60,6764 \\
SN4 & 0,6954 & 35,5504 & 0,7294 & 42,9822 \\
MJ1 & 0,7681 & 55,4515 & 0,6539 & 28,4650 \\
MJ2 & 0,8952 & 200,9777 & 0,8547 & 210,0657 \\
MJ3 & 0,9053 & 158,4810 & 0,9101 & 165,6361 \\
MJ4 & 0,8591 & 96,4675 & 0,7593 & 39,7332 \\
PA1 & 0,5528 & 4,2734 & 0,8209 & 52,3082 \\
PA2 & 0,5557 & 3,8059 & 0,7672 & 36,7449 \\
PA3 & 0,7778 & 6,9692 & 0,7588 & 32,9381 \\
& & & &
\end{tabular}




\begin{tabular}{ccccc}
\hline & & & & \\
PA4 & 0,6151 & 3,8751 & 0,8922 & 129,7346 \\
PA5 & 0,6055 & 3,6527 & 0,8409 & 59,0125 \\
IP1 & 0,8111 & 68,4728 & 0,8446 & 115,2724 \\
IP2 & 0,8152 & 122,2536 & 0,8744 & 199,4011 \\
IP3 & 0,7189 & 44,3684 & 0,7008 & 40,6304 \\
PB1 & 0,9020 & 177,3334 & 0,8834 & 197,2282 \\
PB2 & 0,9096 & 215,8826 & 0,8516 & 106,4920 \\
PB3 & 0,8406 & 99,2749 & 0,8398 & 94,4250 \\
PB4 & 0,8631 & 126,5461 & 0,7685 & 48,9028 \\
\hline VARIABEL & $\mathbf{C R}$ & $\mathbf{A V E}$ & $\mathbf{C R}$ & $\mathbf{A V E}$ \\
\hline SE & 0,9198 & 0,6979 & 0,9347 & 0,7415 \\
PEU & 0,8771 & 0,5497 & 0,8955 & 0,5906 \\
PU & 0,9454 & 0,7765 & 0,9391 & 0,7556 \\
SN & 0,8344 & 0,5584 & 0,7991 & 0,5022 \\
MJ & 0,9179 & 0,7373 & 0,8754 & 0,6407 \\
PA & 0,7608 & 0,4529 & 0,9094 & 0,6683 \\
IP & 0,8257 & 0,6130 & 0,8503 & 0,6564 \\
PB & 0,9316 & 0,7732 & 0,9032 & 0,7004 \\
\hline
\end{tabular}

Dari hasil statistik ditemukan bahwa seluruh item pertanyaan memiliki loading di atas 0,5 sehingga validitas dari item telah terpenuhi. Seluruh nilai AVE variabel dari perhitungan subgroup melebihi 0,5 kecuali nilai AVE variabel penerimaan harga (PA) dari perhitungan laki-laki adalah 0,4529. Namun demikian, item pertanyaan dari variabel PA untuk laki-laki telah memenuhi uji validitas sehingga variabel PA walaupun nilai AVE kurang dari 0,5 tetap layak untuk dilibatkan dalam investigasi. Dalam uji reliabilitas, diketahui nilai CR dari tiap variabel dalam subgrup telah melebihi angka 0,7 sehingga seluruh variabel memenuhi pengujian validitas.

Model struktural diukur dengan metode yang sama yaitu dengan membagi ke dalam kategori gender. Bootstraping menghasilkan perkiraan yang lebih baik dengan sampel yang kecil. Prosedur bootstrapping dijalankan untuk menghasilkan path coefficient dan t-value yang kemudian dijelaskan untuk menentukan signifikansi statistik. Penelitian ini merupakan uji dua sisi (two-tailed test) dengan nilai kritis (critical value) adalah 1,65 (level signifikansi 10\%), 1,96 (level signifikansi 5\%), dan 2,58 (level signifikansi 1\%) (Neupane, Soar, Vaidya, \& Yong, 2014). Selain itu, pengujian struktural menyajikan koefisien determinasi ( $r$ square) yang berguna untuk menjelaskan kekuatan variabel independen dalam menjelaskan variabel dependen. Tabel 2 di bawah ini menyajikan path coefficient dan $t$-value untuk kategori gender.

Seperti yang tersaji dalam Tabel 2 bahwa empat hasil pengujian hubungan terdapat persaamaan hasil antara pengujian mahasiswa dan mahasiswi, sedangkan tiga hubungan lainnya berbeda hasil antara mahasiswa dan mahasiswi. Pertama, hubungan kemahiran diri (SE) terhadap niat untuk melakukan pembajakan (IP) pada mahasiswa berpengaruh positif tetapi tidak signifikan, sedangkan untuk mahasiswi berpengaruh negatif dan signifikan. Kedua, hubungan persepsi kemudahan (PEU) berpengaruh positif signifikan terhadap niat pembajakan untuk mahasiswa, sedangkan pada mahasiswi berpengaruh negatif dan signifikan. Ketiga, pada hubungan penerimaan harga (PA) terhadap niat pembajakan, terdapat hubungan positif tetapi tidak signifikan pada mahasiswa dan negatif signifikan pada mahasiswi. 
Tabel 2. Path coefficient dan $t$-value dari Gender

\begin{tabular}{ccccccc}
\hline \multirow{2}{*}{ Path } & \multicolumn{3}{c}{ MAHASISWA } & \multicolumn{3}{c}{ MAHASISWI } \\
\cline { 2 - 7 } & Path & t-value & Kesimpulan & Path & t-value & Kesimpulan \\
\hline SE - IP & 0,0089 & 0,6150 & td & $-0,0532$ & $3,1411^{*}$ & $\mathrm{~d}$ \\
PEU - & 0,0290 & $2,8470^{*}$ & $\mathrm{~d}$ & $-0,0955$ & $5,3838^{*}$ & $\mathrm{~d}$ \\
PU - IP & 0,4623 & $30,3600^{*}$ & $\mathrm{~d}$ & 0,2933 & $15,9740^{*}$ & $\mathrm{~d}$ \\
SN - IP & 0,0874 & $5,4718^{*}$ & $\mathrm{~d}$ & 0,0369 & $2,3801^{*}$ & $\mathrm{~d}$ \\
MJ - IP & 0,4166 & $21,4463^{*}$ & $\mathrm{~d}$ & 0,6842 & $34,4855^{*}$ & $\mathrm{~d}$ \\
PA - IP & 0,0118 & 0,9910 & $\mathrm{td}$ & $-0,2021$ & $15,6859^{*}$ & $\mathrm{~d}$ \\
IP - PB & 0,5670 & $2,8470^{*}$ & $\mathrm{~d}$ & 0,6449 & $40,4477^{*}$ & $\mathrm{~d}$ \\
\hline
\end{tabular}

$\mathrm{d}=$ didukung; $\mathrm{td}=$ tidak didukung

*signifikansi 1\%; **signifikansi 5\%

\section{Multi-grup Analisis}

Perhitungan multi-grup analisis dengan PLS dengan menghitung pooled-error t-test untuk menentukan signifikansi statistik dari path coefficient yang berbeda berdasarkan gender (Moores dan Chang 2006). Dengan menggunakan pendekatan bahwa sampel tidak terdistribusi normal dan varian dari grup tidak sama maka Smith-Satterthwait test dapat diterapkan (Chin, 2000).

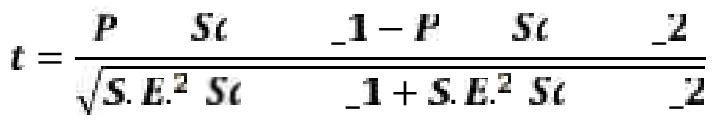

Path sample merujuk pada nilai path coefficient berdasarkan subgrup (gender) sedangkan SE sample merujuk pada nilai standar error dari subgrup. Kedua nilai tersebut secara otomatis tersedia dalam perhitungan bootstrapping. Tabel 3 di bawah ini menyediakan informasi untuk perhitungan nilai t (t-statistic) dengan Smith-Satterthwait test.

Tabel 3. Hasil pooled-error t-test dari Subgrup Gender

\begin{tabular}{cccccc}
\hline \multirow{2}{*}{ Path } & \multicolumn{2}{c}{ MAHASISWA } & \multicolumn{2}{c}{ MAHASISWI } & \multirow{2}{*}{ t-statistic } \\
\cline { 2 - 5 } & Path Coeff. & SE & Path Coeff. & SE & \\
\hline SE - IP & 0,0089 & 0,0145 & $-0,0532$ & 0,0169 & $-0,3505$ \\
PEU - IP & 0,0290 & 0,0102 & $-0,0955$ & 0,0177 & $-0,7454$ \\
PU - IP & 0,4623 & 0,0152 & 0,2933 & 0,0187 & $-0,8853$ \\
SN - IP & 0,0874 & 0,0160 & 0,0369 & 0,0155 & $-0,2845$ \\
MJ - IP & 0,4166 & 0,0194 & 0,6842 & 0,0198 & 1,3516 \\
PA - IP & 0,0118 & 0,0119 & $-0,2021$ & 0,0129 & $-1,3583$ \\
IP - PB & 0,5670 & 0,0192 & 0,6449 & 0,0159 & 0,4158 \\
\hline
\end{tabular}

Seperti yang tersaji dalam tabel 3, temuan dari perhitungan multi-grup analisis dari gender dilihat pada nilai $t$-statistic tidak ada satupun hasil yang signifikan. Hasil tersebut menunjukan bahwa antara mahasiswa dan mahasiswi tidak terdapat perbedaan dalam perilaku pembajakan dan illegal download baik masih berupa niat maupun perilaku pembajakan yang nyata.

\section{Diskusi}

Individu (atau penelitian) mempelajari peran gender dalam kehidupan masyarakat termasuk perilaku yang didasarkan spesifik berdasarkan gender (Srite \& Karahanna, 2006). Penelitian ini ditujukan untuk menjawab hipotesis yang dikembangkan "apakah ada 
perbedaan mahasiswa dengan mahasiswi dalam perilaku pembajakan". Secara umum, tidak ada perbedaan antara mahasiswa dan mahasiswi dalam hal pembajakan produk digital di Indonesia (lihat multi-grup analisis).

Investigasi didasarkan pada faktor teknologi yang terdapat pada gender. Penelitian ini menginvestigasi dari sisi kemahiran diri (self-efficacy) (Bandura, 1977) yang dikembangkan ke dalam computer self-efficacy (CSE). CSE secara umum didefinisikan sebagai penilaian individu atas kemampuannya untuk menggunakan computer (Compeau \& Higgins, 1995; He \& Freeman, 2010). Menurut He \& Freeman (2010) laki-laki memiliki orientasi lebih dan berpengalaman terhadap komputer daripada perempuan. Seperti yang telah diasumsikan bahwa laki-laki (mahasiswa) dengan keahliannya menggunakan komputer akan memiliki tendensi yang lebih tinggi terhadap pembajakan. Berdasarkan hasil penelitian, asumsi itu tidak dapat dibuktikan dengan baik karena secara statistik hubungan kemahiran diri dengan niat pembajakan pada mahasiswa positif dan tidak signifikan. Berlawanan dengan hasil pada mahasiswi yang berpengaruh negatif dan signifikan. Hasil tersebut menjadi pertanyaan mengapa mahasiswa dengan keahliannya tidak signifikan melakukan pembajakan sedangkan mahasiswi dengan keahlian yang semakin tinggi secara signifikan tidak memiliki niat melakukan pembajakan. Alasannya adalah terdapat motif yang berbeda antara mahasiswa dan mahasiswi dalam pembajakan. Mahasiswa cenderung menyukai untuk menggunakan file-sharing (transfer file antar gadget/smartphone) daripada mengunduh atau melakukan pembajakan, sedangkan mahasiswi mempertimbangkan resiko dari penggunaan dari produk bajakan serta lebih memiliki keinginan untuk membayar produk digital yang asli (Chiang \& Assane, 2008).

Dalam konteks kemudahan dalam memperoleh dan menggunakan produk bajakan, mahasiswa dan mahasiswi memiliki pandangan yang berbeda dan signifikan. Mahasiswa lebih mengeskplorasi kemudahan yang ditawarkan oleh teknologi informasi dalam memperoleh produk digital meskipun dengan membajak atau file sharing, sedangkan pada mahasiswi walaupun berorientasi pada kemudahan tidak tertarik untuk melakukan pembajakan. Hal ini disebabkan karena adanya persepsi yang berbeda terhadap harga yang ditetapkan (lihat Tabel 2). Namun demikian jika dihadapkan pada manfaat, mahasiswa dan mahasiswi sepakat bahwa manfaat dari produk digital adalah sama dengan aslinya sehingga menimbulkan niat pembajakan. Mereka percaya bahwa manfaat dari produk bajakan sama dengan aslinya yang memiliki kemampuan yang sama dalam mendukung aktivitasnya. Sebagai contoh, untuk memperoleh buku acuan pembelajaran, mahasiswa dan mahasiswi cenderung lebih menyukai untuk mencari softcopy atau e-book dari buku acuan tersebut di internet.

Persepsi harga dalam penelitian di area pembajakan digital menjadi faktor kunci untuk diteliti. Carmen et al. (2014) memandang penerimaan harga mempunyai peran dalam pembajakan karena harga dari produk digital asli dianggap tidak adil dan tidak terjangkau. Penelitian ini menemukan bahwa mahasiswa sulit untuk menerima harga yang ditetapkan, sedangkan mahasiswi menerima harga dari produk digital asli. Mahasiswa lebih menekankan pada sisi manfaat dari suatu produk digital. Mereka lebih menyukai untuk melakukan pembajakan yang dapat meminimalkan pengeluaran daripada harus membayar dengan mengabaikan resiko. Kontradiktif dengan mahasiswa, mahasiswi lebih menekankan pada menghindari resiko yang ditimbulkan akibat menggunakan produk bajakan. Resiko dalam hal ini adalah resiko atau dampak negatif terhadap gadget/smartphone (seperti virus, malware, dll) bukan resiko legal seperti yang diteliti oleh Vida, Koklic, Kukar-Kinney, \& Penz (2012). Sehingga, mahasiswi lebih baik mengeluarkan hartanya untuk membeli produk yang asli daripada menanggung resiko.

Investigasi berikutnya didasarkan pada moral dan pengaruh sosial dalam perilaku pembajakan. Sebagai upaya penanggulangan penyalahgunaan hak cipta dari tujuan komersial yang negatif seperti pembajakan, Pemerintah Indonesia telah memberikan perhatian terhadap 
para kreator dengan menerbitkan Undang-Undang Nomor 28 Tahun 2014 Tentang Hak Cipta untuk melindungi hak cipta yang telah diciptakan. Artinya, dengan Undang-Undang (UU) tersebut ada harapan bagi kreator bahwa ciptaannya mendapat perlindungan. Pembajakan esensinya adalah sebuah pencurian yang tidak dengan kuat digolongkan ke perilaku kriminal yang harus memperoleh tindakan hukum (Balestrino, 2008). Namun fakta yang dihasilkan dari penelitian ini menemukan bahwa moral dari mahasiswa dan mahasiswi tidak menganggap serius apa yang diatur dalam UU. Tren di Indonesia, pembajakan lebih banyak dilakukan dengan melakukan ilegal download di website tertentu yang menyediakan produk digital dan banyak terjadi di dunia akademik (Tjiptono et al., 2016). Arli \& Tjiptono (2016) berargumen bahwa mahasiswa dan mahasiswi di Indonesia tidak takut dengan pembajakan yang telah dilakukannya tersebut. Dengan hasil penelitian ini memperkuat argumen Arli \& Tjiptono (2016) bahwa dilihat dari gender tidak terdapat perbedaan bahwa baik mahasiswa maupun mahasiswi tidak memperdulikan aturan hukum dan moral walaupun menurut $\mathrm{Al}$ rafee \& Cronan (2006) seorang perempuan memiliki standar moral yang lebih tinggi.

Terlepas dari penjelasan di atas, mereka memiliki alasan untuk menjustifikasi mengapa pembajakan dilakukan. Menurut neutralization theory, seseorang yang melakukan perilaku yang dianggap salah akan dijustifikasi ke dalam perilaku yang normal (Chatzidakis et al., 2004). Salah satu faktor munculnya justifikasi adalah perilaku pembajakan sudah sangat umum dilakukan oleh semua orang yang termasuk orang-orang disekitar pelaku sehingga menjadi perilaku yang dibenarkan. Akibatnya akan terdapat pengaruh yang signifikan terhadap perilaku pembajakan (Hinduja, 2007). Fakta empiris dari Phau et al. (2014) menujukan bahwa tekanan dari lingkungan memunculkan keinginan untuk melakukan pembajakan. Hasil penelitian ini menerangkan bahwa tidak terdapat perbedaan antara mahasiswa dan mahasiswi dalam menerima tekanan dari sosial dan lingkungan untuk melakukan pembajakan. Baik mahasiswa dan mahasiswi menerima dengan baik tekanan atau pengaruh yang mereka peroleh untuk dikonversikan ke dalam perilaku pembajakan. Sebagai contoh, untuk mencari jurnal ilmiah di internet (emerald, science direct, dll), lingkungan akademis telah terbiasa untuk mengunduh secara ilegal melalui website penyedia, secara otomatis pengaruh ini akan mempengaruhi mahasiswa dan mahasiswi untuk melakukan hal yang sama.

\section{KESIMPULAN}

Penelitian ini bertujuan untuk menginvestigasi peran gender dalam perilaku pembajakan. Secara keseluruhan dengan menggunakan pengujian Smith-Satterthwait test tidak menunjukan adanya perbedaan antara mahasiswa dan mahasiswi pada perilaku pembajakan. Namun terdapat beberapa hasil yang berbeda dari relasi variabel apabila diteliti dengan perhitungan terpisah antara mahasiswa dan mahasiswi. Investigasi dilakukan dengan menggunakan faktor teknologi (TAM), penerimaan harga, serta moral dan pengaruh sosial. Penelitian ini secara khusus memperluas literatur mengenai gender pada TAM terhadap perilaku pembajakan yang saat ini belum banyak perhatian karena masih bergantung pada TPB (Yoon 2011; Phau et al. 2014). Dengan menggunakan TAM, khususnya pada variabel persepsi kemudahan dan manfaat telah mampu meningkatkan investigasi tanpa harus selalu menggunakan TPB walaupun Phau et al. (2014) beranggapan bahwa TPB adalah model yang efektif untuk menjelaskan pembajakan. Persepsi manfaat telah disepakati baik mahasiswa maupun mahasiswi memiliki daya tarik yang luar biasa untuk melakukan pembajakan. Produk bajakan sangat sulit dibedakan dengan aslinya karena memiliki tampilan dan manfaat yang sama. Hal yang sama juga terjadi pada moral, mahasiswa dan mahasiswi telah mengetahui bahwa terdapat aturan hukum yang melarang pembajakan. Namun demikian, dalam hal ini mahasiswa, mereka tidak takut terhadap ancaman dari hokum atas pembajakan karena didukung dengan justifikasi bahwa pembajakan sudah sangat umum terjadi di lingkungan sosial masyarakat. 
Penelitian ini memberikan literatur tambahan pada investigasi perilaku pembajakan di Indonesia. Berdasarkan pada temuan penelitian ini, perusahaan dan pemerintah perlu meningkatkan kewaspadaan terhadap pembajakan digital karena secara umum tidak mengenal gender. Walaupun sudah terdapat UU yang mengatur larangan pembajakan, terbukti bahwa UU tersebut "tidak ditakuti" oleh masyarakat karena belum adanya role model yang dapat menjadi bukti bahwa UU tersebut secara tegas diterapkan. Didasari pada fakta bahwa produk digital bajakan memiliki manfaat yang sama dengan aslinya. Hasil penelitian ini memberi saran kepada industri produk digital untuk menghitung kembali harga jual dari produk digital. Pemerintah juga perlu untuk menerapkan sistem blokir website untuk web yang menyediakan konten bajakan yang memungkinkan untuk dapat diunduh secara masal. Selain itu, penelitian ini terbatas pada aspek yang dibahas pada gender yang memiliki ruang lingkup yang sempit. Responden penelitian juga masih terbatas pada mahasiswa dan mahasiswi yang belum mampu merepresentasikan seluruh masyarakat. Penelitian ini juga masih menggunakan asumsi ilmiah yang diambil dari pengujian gender pada penerimaan teknologi yang kemudian diasumsikan ke dalam pengujian pembajakan digital. Penelitian selanjutnya diharapkan mampu memeroleh responden dengan cakupan yang lebih luas. Selain itu pengembangan model yang membahas faktor pengalaman dan juga kondisi yang memfasilitasi akan lebih jauh menjelaskan pembajakan. Penelitian selanjutnya perlu juga untuk menambah variabel seperti persepsi resiko yang dalam penelitian ini tidak diuji yang sebenarnya adalah salah satu faktor yang fundamental.

\section{DAFTAR PUSTAKA}

Abbasi, M. S., Chandio, F. H., Soomro, A. F., \& Shah, F. (2011). Social influence, voluntariness, experience and the internet acceptance: An extension of technology acceptance model within a south-Asian country context. Journal of Enterprise Information Management, 24(1), 30-52.

Ajzen, I., The Theory of Planned Behavior. Organizational Behavior and Human Decision Processes, 50, 179-211.

Al-rafee, S., \& Cronan, T. P. (2006). Digital Piracy : Factors that Influence Attitude Toward Behavior. Journal of Business Ethics, 63, 237-259.

Anderson, N., Lankshear, C., Timms, C., \& Courtney, L. (2008). Because it' s boring, irrelevant and I don ' t like computers ': Why high school girls avoid professionallyoriented ICT subjects. Computer \& Education, 50, 1304-1318.

Arli, D., \& Tjiptono, F. (2016). Consumer digital piracy behaviour among youths: insights from Indonesia. Asia Pacific Journal of Marketing and Logistics, 28(5), 898-922. 3

Arli, D., Tjiptono, F., \& Porto, R. (2015). The impact of moral equity, relativism and attitude on individuals' digital piracy behaviour in a developing country. Marketing Intelligence \& Planning, 33(3), 348-365.

Balestrino, A. (2008). It is a theft but not a crime. European Journal of Political Economy, $24,455-469$.

Bandura, A. (1977). Self-efficacy: Toward a Unifying Theory of Behavioral Change. Psychological Reports, 84(2), 191-215.

Bender, M. T., \& Wang, Y. (2009). The Impact of Digital Piracy on Music Sales : A CrossCountry Analysis. International Social Science Review, 84(3/4), 157-170. 
Bossuyt, S., \& Van Kenhove, P. (2016). Assertiveness Bias in Gender Ethics Research: Why Women Deserve the Benefit of the Doubt. Journal of Business Ethics. 150(3), 727-739.

Carmen, C., Carmen, A., \& Javier, R. (2014). Technological and ethical antecedents of ebook piracy and price acceptance: Evidence from Spanish case. The Electronic Library, 32(4), 542-566.

Chan, R. Y. K., Ma, K. H. Y., \& Wong, Y. H. (2013). The Software Piracy Decision-Making Process of Chinese Computer Users. The Information Society: An International Journal, 29, 37-41.

Chatzidakis, A., Hibbert, S., Mittusis, D., \& Smith, A. (2004). Virtue in Consumption? Journal of Marketing Management, 20, 527-544.

Chiang, E. P., \& Assane, D. (2008). Music piracy among students on the university campus : Do males and females react differently? The Journal of Socio-Economics, 37, 13711380 .

Chin, W. W. (2000). Frequently Asked Questions - Partial Least Squares \& PLS Graph. http://disc-nt.cba.uh.edu/chin/plsfaq/plsfaq.htm. (diakses 30 April 2017)

CNN Indonesia. (2016). Pengguna Internet di Indonesia Didominasi Anak Muda. http://www.cnnindonesia.com/teknologi/20161024161722-185-167570/penggunainternet-di-indonesia-didominasi-anak-muda/.(diakses 30 April 2017)

Cockrill, A., \& Goode, M. M. H. (2012). DVD pirating intentions: Angels , devils , chancers and receivers. Journal of Consumer Behavior, 11, 1-10.

Compeau, D. R., \& Higgins, C. A. (1995). Application of Social Cognitive Theory to Training for Computer Skills. Information sSystem Research, 6(2), 118-143.

Cronan, T., \& Al-rafee, S. (2008). Factors that Influence the Intention to Pirate Software and Media. Journal of Business Ethics, 78, 527-545.

Davis, F. D. (1989). Perceived Usefulness, Perceived Ease of Use, and User Acceptance of Information Technology. Information Technolog MIS Quarterly, 13(3), 319-340.

Easley, R. F. (2005). Ethical Issues in the Music Industry Response to Innovation and Piracy. Journal of Business Ethics, 62, 163-168.

Gefen, D., Straub, D. W., \& Boudreau, M. C. (2000). Structural equation modeling and regression: guidelines for research practice. Commucication of the Association for Information Systems, 4(1), 1-77.

Hair, J. F. J., Black, W. C., Babin, B. J., Anderson, R. E., \& Tatham, R. L. (2010). Multivariate Data Analysis. New Jersey: Prantice Hall.

He, J., \& Freeman, L. A. (2010). Are Men More Technology-Oriented Than Women? The Role of Gender on the Development of General Computer Self-Efficacy of College Students. Journal of Information Systems Education, 21(2), 203-212.

Hinduja, S. (2007). Neutralization theory and online software piracy: An empirical analysis. Ethics and Information Technology, 9, 187-204. 
Jackman, M., \& Torde, T. (2014). Why buy when we can pirate? the role of intentions and willingness to pay in predicting piracy behavior. International Journal of Social Economics, 41(9), 801-819.

Jacobs, R. S., Heuvelman, A., Tan, M., \& Peters, O. (2012). Computers in Human Behavior Digital movie piracy: A perspective on downloading behavior through social cognitive theory. Computers in Human Behavior, 28(3), 958-967.

Jakarta Globe. (2017). Now Playing: Indonesia's Piracy Problem Takes on a New Dimension Online. Retrieved from http://jakartaglobe.id/news/now-playingindonesias-piracy-problem-takes-new-dimension-online/. (diakses 30 April 2017).

Jennings, S. E., \& Onwuegbuzie, A. J. (2001). Computer Attitudes as a Function of Age , Gender, Math Attitude, And Developmental Status. Journal Educational Computing Research, 25(4), 367-384.

McGuire, B. (2009). Brett McGuire: Reasons We Buy Counterfeit Goods. http://jakartaglobe.id/archive/brett-mcguire-reasons-we-buy-counterfeit-goods/. (diakses 30 April 2017)

Moghaddam, G. G. (2010). Information technology and gender gap: toward a global view. The Electronic Library, 28(5), 722-733.

Moores, T. T., \& Chang, J. C. (2006). Ethical Decision Making in Software Piracy: Initial Development and Test of a Four-Component Model. MIS Quarterly, 30(1), 167-180.

Neupane, A., Soar, J., Vaidya, K., \& Yong, J. (2014). Willingness to adopt e-procurement to reduce corruption. Transforming Government: People, Process and Policy, 8(2), 283308.

Phau, I., \& Liang, J. (2012). Downloading digital video games: predictors , moderators and consequences. Marketing Intelligence \& Planning, 30(7), 740-756.

Phau, I., Lim, A., Liang, J., \& Lwin, M. (2014). Engaging in Digital Piracy of Movies: a Theory of Planned Behavior Approach. Internet Research, 24(2), 246-266.

Popovich, P. M., Gullekson, N., \& Morris, S. (2008). Comparing attitudes towards computer usage by undergraduates from 1986 to 2005. Computers in Human Behavior, 24, 986992.

Roxas, M. L., \& Stoneback, J. Y. (2004). The Importance of Gender Across Cultures in Ethical Decision-Making. Journal of Business Ethics, 50, 149-165.

Srite, M., \& Karahanna, E. (2006). The Role of Espoused National Cultural in Technology Acceptance. MIS Quarterly, 30(3), 679-704.

Sudler, H. (2013). Effectiveness of anti-piracy technology : Finding appropriate solutions for evolving online piracy. Business Horizons, 56(2), 149-157.

Swinyard, W. R., Rinne, H., \& Keng Kau, A. (1990). The Morality of Software Piracy : A Cross-Cultural Analysis. Journal of Business Ethics, 9, 654-664.

Tjiptono, F., Arli, D., \& Viviea. (2016). Gender and digital privacy: Examining determinants of attitude toward digital piracy among youths in an emerging market. International Journal of Consumer Studies, 40(2), 168-178. 
Vekiri, I., \& Chronaki, A. (2008). Gender issues in technology use : Perceived social support , computer self-efficacy and value beliefs, and computer use beyond school. Computer \& Education, 51, 1392-1404.

Venkatesh, V., \& Bala, H. (2008). Technology acceptance model 3 and a research agenda on interventions. Decision Sciences, 39(2), 273-315.

Venkatesh, V., \& Morris, M. G. (2000). Why Don't Men Ever Stop to Ask for Directions ? Gender, Social Influence, And Their Role In Technology And Usage Behavior. MIS Quarterly, 24(1), 115-139.

Vida, I., Koklic, M. K., Kukar-Kinney, M., \& Penz, E. (2012). Predicting consumer digital piracy behavior: The role of rationalization and perceived consequences. Journal of Research in Interactive Marketing, 6(4), 298-313.

Widiartanto, Y. H. (2016). 2016, Pengguna Internet di Indonesia Capai 132 Juta. http://tekno.kompas.com/read/2016/10/24/15064727/2016.pengguna.internet.di.indone sia.capai.132.juta. (diakses 30 April 2017).

Wuysang, J. H. (2015). Indonesian music sales now 95.7 percent piracy. http://www.thejakartapost.com/news/2015/09/18/indonesian-music-sales-now-957percent-piracy.html. (diakses 30 April 2017).

Yoon, C. (2011). Theory of Planned Behavior and Ethics Theory in Digital Piracy: An Integrated Model. Journal of Business Ethics, 100, 405-417.

Zhang, L., Nyheum, P., \& Mattila, A. S. (2014). The effect of power and gender on technology acceptance. Journal of Hospitality and Tourism Technology, 5(3), 299314.

Zimerman, M. (2011). E-books and piracy : implications / issues for academic libraries. New Library World, 112(1/2), 67-75. 